\title{
Rainfall simulation study of the impact of unsealed roads in Cardinia Shire
}

\author{
S. J. Riley \& S. Shrestha \\ Sustainable Engineering and Technology Research Group, \\ University of Western Sydney, Australia
}

\begin{abstract}
Cardinia Shire Council, the City of Casey, and Mornington Peninsula Shire Council, with funding from the EPA Victoria as part of the Victorian Stormwater Action Program (VSAP), undertook an investigation of the impact of unsealed roads on stormwater quality. The aim of the project was to identify ways to minimise the impact of sediment runoff from the unsealed road network on the receiving waters of Western Port Bay and its tributaries by reviewing and investigating best practice road maintenance measures. Various road treatments were trialled to examine how road-surfacing techniques on unsealed roads affect sediment runoff and storm water quality. Rainfall simulation was employed as an effective method to facilitate the rapid completion of the project. This paper reports on the experimental set-up, issues involved in the experimental method, and some of the results on the effectiveness of different road treatments
\end{abstract}

Keywords: rainfall simulation, road stability, off-site impacts, hydrology, erosion, stormwater.

\section{Introduction}

Erosion of unsealed road surfaces is known to cause a number of problems of road surface and bank stability and off-road pollution, the latter caused by transport of contaminated sediments and the impact of the increased mass and character of sediment washed from the roads. A number of studies in urban, rural and forested areas have established the nature of the problem and developed models for predicting the likely rates of erosion [1-7].

Despite the significant investment of funds to seal rural roads, many smaller rural roads in Australia are unpaved [8] - 41.6\% paved of the $810,641 \mathrm{~km}$ of road 
in Australia. There are obvious financial and environmental benefits in developing road pavement, maintenance, and erosion control strategies that reduce the off-site impact of road erosion.

Cardinia Shire Council, City of Casey and Mornington Peninsula Shire Council, with funding from the EPA Victoria as part of the Victorian Stormwater Action Program (VSAP), undertook an investigation of the impact of unsealed roads on stormwater quality. The aim of the project was to minimise the impact of sediment runoff from the unsealed road network in Cardinia, Casey and Mornington Peninsula municipalities on the receiving waters of Western Port Bay and its tributaries, by reviewing and investigating best practice road maintenance measures.

Several road treatments were trialled to examine how road-surfacing techniques on unsealed roads affect sediment runoff and storm water quality. The large-scale rainfall simulator developed by Riley and Hancock [9] was employed to facilitate the rapid completion of the project. Rainfall simulations are a well-established tool in erosion and hydrology research, although issues of spatial variability and representativeness of simulated rainfall have to be considered [10-15]. There have been many designs (e.g. [16]) and the simulator of Riley and Hancock [9], developed for large-scale studies, is a modification and uses design aspects of earlier simulators. This paper presents details of the rainfall simulation experiment and the hydrological analysis of the data collected. The focus is on the methodology and issues in running the experiment.

\section{Method}

The experimental site at Boes Rd, between Graydens Rd and Hodgins Rd in Hastings, Victoria, Australia (Fig. 1) involved seven road surface treatments and one control to test the effectiveness of road construction techniques to reduce sediment generation. The treatment section was constructed in series along a $1150 \mathrm{~m}$ length of unsealed road. The proposed sampling strategy is presented in Figure 2.

The treatments included wet and dry compaction, three different stabilisers, a wearing course, and a $6 \%$ cross grade, steeper than the control site (Table 1). The Test plot was a trial to familiarise all participants with the operation of the simulator, construction of plots and collection of data, as well as to collect a reference set of data.

Within each treatment area, two experimental plots (approximately $10 \mathrm{~m}$ along the road $\times 2.5 \mathrm{~m}$ wide, from road crest to gutter) were used to compare the sediment load and water quality of stormwater runoff from each of the road sections. On each plot, three rainfall intensities were simulated. An additional 1 in 50 year storm was conducted on the control site. Water was supplied from a non-potable source and transported to the site by water cart and held in a temporary pool on site. Simulation experiments were to run for 15 minutes, and runoff was recorded in 30-second intervals. Water samples were taken at 30second intervals. 

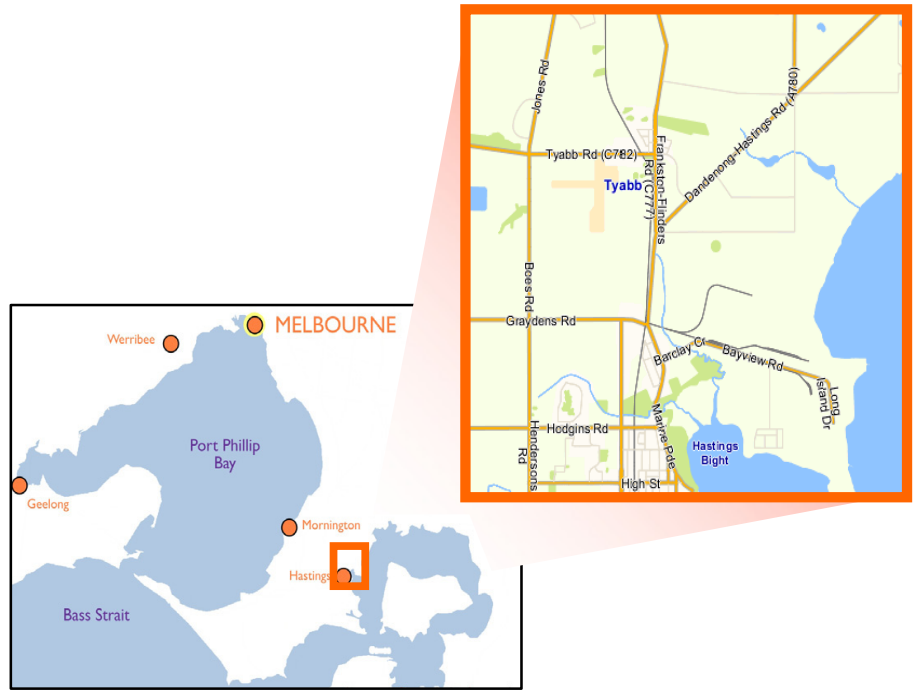

Figure 1: $\quad$ Location map.

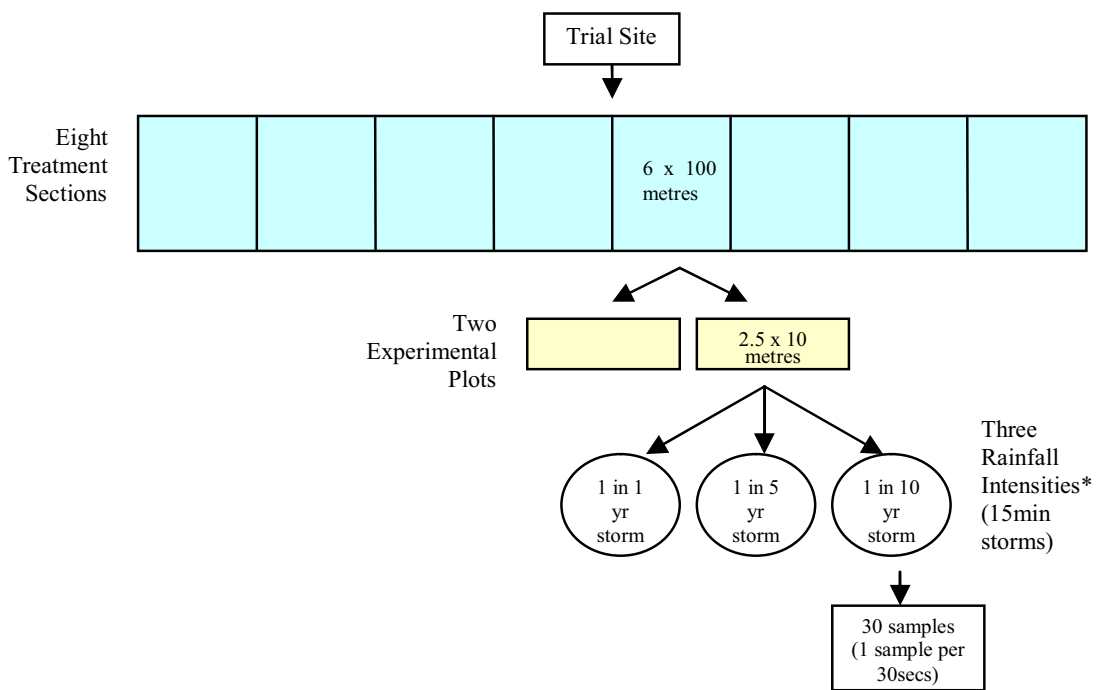

Figure 2: $\quad$ Proposed sampling strategy.

The targeted rainfall intensities identified from local IFD data and Bureau of Meteorology information were:

$\begin{array}{lr}\text { ARI (yrs) } & \mathrm{mm} / \mathrm{h} \\ 1 & 28 \\ 5 & 36 \\ 10 & 58 \\ 50 \text { (for control) } & 85\end{array}$


Dunkerley [15] has noted that many rainfall simulation experiments choose extreme rainfall intensities and long durations. This was not the case for this study.

Sediment samples were taken from the road surface and the roadside drains. Water samples were also taken from the roadside table drains to investigate sediment production from table drains and the effect of various drain treatments on sediment production.

As a result of several difficulties in the field, including running out of time, the sampling sites were reduced to those outlined in Table 2 .

\section{Rainfall simulation}

The rainfall simulation provided some logistical problems in the supply of water. All water had to be delivered to site in a tanker and sourced from a site that did not affect local water supplies, as the area was short of water.

Only half of the road could be used at one time, because it was still a thoroughfare. Appropriate risk management and traffic control plans were developed. Issues of working on road sites are presented in Riley and Shrestha [16].

The rainfall simulator fits into a 20 -foot container, and this provided storage on site during the night. Power was supplied from a 25KVA generator. Because of the number of persons working on site toilet and catering facilities had to be supplied, along with first aid equipment. It was necessary to mount a security guard at night.

The first set of rainfall simulations were conducted on the trial site (the benchmark). Several abortive attempts were made. The test plot was the first plot constructed on the site. It was constructed in loose sand on the margin of the road. It was a learning experience for all involved. The trough was not properly sealed to the face of the cut of the plot, the depth of the medium to coarse sand deposit in which it was constructed was greater than the interception trench depth, and so considerable groundwater flow was able to escape from the plot. It was not possible to adequately seal the face. As a result the test results are considered to be of little use. However, the simulation experiment demonstrated that the substantial body of loose sand along the margins of the road had significant water storage and filtering capacity, which reduced the runoff from the plot and resulted in no runoff in the first run. Subsequent sites took account of the experience of the test site and few leaks or problems were encountered in conducting the experiments.

Simulations tended to be held early in the morning, to avoid problems with wind-drift, but this did not delay the work as the sequence of simulation runs took less than $2 \mathrm{hrs}$ to complete at a site and the majority of the time was spent in preparing a site and moving equipment onto it.

The rainfall stands were placed at $5 \mathrm{~m}$ intervals on the equilateral triangle pattern. The layout is shown in Figure 3.

Where paired plots were used the simulations were conducted at the same time in a simulation run. The simulator easily covered the larger area. Runoff 
from a plot was collected in a PVC trough running along the margin of the road, and directed into a RBC flume, at which discharge was measured and sediment samples collected. Any sediment remaining in the trough or approach to the flume at the end of a simulation run was collected for drying and weighing.

Table 1: $\quad$ Treatments and final sampling plan.

\begin{tabular}{|c|c|c|}
\hline $\begin{array}{c}\text { Treatment } \\
\text { Number }\end{array}$ & Description & Actual \\
\hline Test site & $\begin{array}{l}\text { - } 100 \text { mm local gravel base course } \\
\text { - Dry compaction } \\
\text { - } 3 \% \text { crossfall }\end{array}$ & \\
\hline K (Control) & $\begin{array}{l}\text { Control Site: } \\
\text { - } 100 \text { mm local gravel base course } \\
\text { - Dry compaction } \\
\text { - } 3 \% \text { crossfall } \\
\text { Road site with no treatment other than was } \\
\text { standard for the whole of the road at time } \\
\text { of construction and during maintenance }\end{array}$ & \\
\hline A & $\begin{array}{l}\text { - } 100 \mathrm{~mm} \text { local gravel base course } \\
\text { - Wet compaction } \\
\text { - } 3 \% \text { crossfall }\end{array}$ & \\
\hline B & $\begin{array}{l}\text { - } 100 \mathrm{~mm} \text { local gravel base course } \\
\text { - Wet compaction } \\
\text { - } 6 \% \text { crossfall }\end{array}$ & $\begin{array}{l}\text { Treatments } \mathrm{B} \text { and } \mathrm{F} \text { were not } \\
\text { assessed because the cross-fall was } \\
\text { not at } 6 \% \text { as a result of post- } \\
\text { construction settlement }\end{array}$ \\
\hline $\mathrm{C}$ & $\begin{array}{l}\text { - } 100 \mathrm{~mm} \text { local gravel base course plus } \\
70 \mathrm{~mm} \text { wearing course } \\
\text { - Wet compaction } \\
\text { - } 6 \% \text { crossfall }\end{array}$ & \\
\hline $\mathrm{D}$ & $\begin{array}{l}\text { - } 100 \mathrm{~mm} \text { local gravel base course } \\
\text { - Wet compaction } \\
\text { - } 6 \% \text { crossfall } \\
\text { - } \mathrm{MgCl}\end{array}$ & $\begin{array}{l}\text { Only single plots were constructed } \\
\text { on D and E, partly to reduce the } \\
\text { time and cost of the experiment } \\
\text { and also because the treatments } \\
\text { were specific to particular } \\
\text { stabilisers and indications of the } \\
\text { success of the stabilisers was } \\
\text { sufficient for the study. }\end{array}$ \\
\hline $\mathrm{E}$ & $\begin{array}{l}\text { - } 100 \mathrm{~mm} \text { local gravel base course } \\
\text { - Wet compaction } \\
\text { - } 6 \% \text { crossfall } \\
\text { - lignosulfonate }\end{array}$ & $\begin{array}{l}\text { Only single plots were constructed } \\
\text { on D and E, partly to reduce the } \\
\text { time and cost of the experiment } \\
\text { and also because the treatments } \\
\text { were specific to particular } \\
\text { stabilisers and indications of the } \\
\text { success of the stabilisers was } \\
\text { sufficient for the study. }\end{array}$ \\
\hline $\mathrm{F}$ & $\begin{array}{l}\text { - } 100 \mathrm{~mm} \text { local gravel base course } \\
\text { - Wet compaction } \\
\text { - } 6 \% \text { crossfall } \\
\text { - Bitumen emulsion }\end{array}$ & $\begin{array}{l}\text { Treatments } \mathrm{B} \text { and } \mathrm{F} \text { were not } \\
\text { assessed because the cross-fall was } \\
\text { not at } 6 \% \text { as a result of post- } \\
\text { construction settlement }\end{array}$ \\
\hline G & $\begin{array}{l}\text { - } 100 \text { mm local gravel base course } \\
\text { - Dry compaction } \\
\text { - } 6 \% \text { crossfall }\end{array}$ & \\
\hline
\end{tabular}


Table 2: $\quad$ Final sampling site.

\begin{tabular}{|c|c|c|c|c|}
\hline \multirow[b]{2}{*}{ Surface Treatment } & \multicolumn{2}{|c|}{ Plot 1} & \multicolumn{2}{|c|}{ Plot 2} \\
\hline & $\begin{array}{c}\text { Area } \\
\left(\mathrm{m}^{2}\right)\end{array}$ & $\begin{array}{c}\text { Number of } \\
\text { runs }\end{array}$ & $\begin{array}{c}\text { Area } \\
\left(\mathrm{m}^{2}\right)\end{array}$ & $\begin{array}{c}\text { Number of } \\
\text { runs }\end{array}$ \\
\hline Test plot & 20.6 & 2 & $\mathrm{~N} / \mathrm{A}$ & \\
\hline Treatment A & 25.6 & 2 & 24.8 & 4 \\
\hline Treatment C & 32.2 & 3 & 33.1 & 3 \\
\hline Treatment D & 32.5 & 3 & N/A & \\
\hline Treatment E & 31.8 & 3 & $\mathrm{~N} / \mathrm{A}$ & \\
\hline $\begin{array}{c}\text { Treatment K } \\
\text { (control) }\end{array}$ & 30.4 & 3 & 29.4 & 3 \\
\hline
\end{tabular}

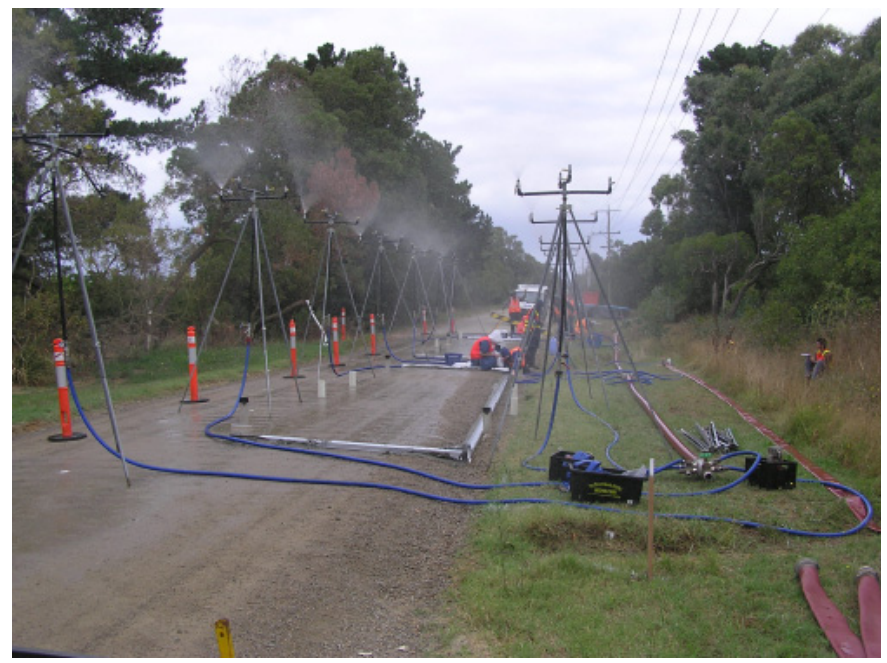

Figure 3: $\quad$ Rainfall simulation on site B.

Water samples were tested for conductivity, $\mathrm{pH}$ and suspended load. The grain size distribution was measured for some of the suspended sediment samples.

Rainfall stands for the simulator were located outside of the plots to reduce the contribution of leakage from the stands to the runoff of the plots.

Rainfall intensity for specific simulation runs often did not meet the designed intensity. These variations arose because of slight differences in pressure, variations in winds, the fact that some rain gauges were not exactly vertical, and slight differences in the nozzles on each of the rain stands. A period was set aside to conduct some calibration experiments on the simulator on site to support previous calibrations, but strong winds in the first three days and the urgency to get the simulation experiments underway meant that this work was not adequately done.

Normally the repetition of simulation experiments allows bracketing of the desired rainfall intensities if they are not achieved immediately. There was no 
opportunity for repetition. The Christiansen Uniformity Coefficient for the rainfall pattern (based on a minimum of 5 rain gauges for each site, spread around the margins of the plots) was greater than $75 \%$ for most simulations. Details of the rainfall are provided in Table 3.

Table 3: $\quad$ Simulated rainfall characteristics.

\begin{tabular}{|c|c|c|c|c|c|c|c|c|c|c|}
\hline \multirow[b]{2}{*}{ Surface Treatment } & \multirow{2}{*}{$\begin{array}{l}\text { Plot } \\
\text { No. }\end{array}$} & \multirow{2}{*}{$\begin{array}{l}\text { Run } \\
\text { No. }\end{array}$} & \multirow[t]{2}{*}{ Nozzle } & \multirow[t]{2}{*}{ Pressure } & \multicolumn{2}{|c|}{ Rainfall } & \multirow[b]{2}{*}{ Duration } & \multirow[b]{2}{*}{ Intensity } & \multirow[b]{2}{*}{$\begin{array}{c}\text { Target } \\
\text { Intensit } \\
y\end{array}$} & \multirow[b]{2}{*}{$\begin{array}{c}\text { Actual } \\
\text { ARI }\end{array}$} \\
\hline & & & & & Depth & Volume & & & & \\
\hline & & & & $\mathrm{kPa}$ & $(\mathrm{mm})$ & $(L)$ & $\min$ & $\mathrm{mm} / \mathrm{h}$ & $\mathrm{mm} / \mathrm{h}$ & yrs \\
\hline \multirow[t]{4}{*}{ Test } & 1 & 1 & $1 \mathrm{~S}$ & 100 & 5.3 & 110 & 15 & 21 & 28 & 0.5 \\
\hline & & 2 & $2 S$ & 80 & 14.6 & 303 & 15 & 58 & 36 & 10 \\
\hline & 1 & 1 & $1 \mathrm{~S}$ & 100 & 6.2 & 160 & 15 & 25 & 28 & 1 \\
\hline & & 2 & $2 S$ & 70 & 10.7 & 275 & 15 & 43 & 36 & 4 \\
\hline \multirow[t]{6}{*}{ Treatment A } & & 1 & $1 \mathrm{~S}$ & 100 & 7.6 & 188 & 15 & 30 & 28 & 1 \\
\hline & & 2 & $2 S$ & 100 & 10.4 & 257 & 15 & 42 & 36 & 3 \\
\hline & 2 & 3 & $1 \mathrm{~L}$ & 60 & 19 & 470 & 15 & 76 & 58 & 40 \\
\hline & & 4 & $1 \mathrm{~L}, 1 \mathrm{~S}$ & 70 & 22.7 & 559 & 15 & 91 & 85 & 90 \\
\hline & & 1 & $1 \mathrm{~S}$ & 100 & 6.8 & 220 & 15 & 27 & 28 & 1 \\
\hline & 1 & 2 & $2 S$ & 70 & 11.4 & 368 & 15 & 46 & 36 & 4 \\
\hline \multirow[t]{5}{*}{ Treatment C } & & 3 & $1 \mathrm{~L}$ & 60 & 13.8 & 445 & 12 & 69 & 58 & 20 \\
\hline & & 1 & $1 \mathrm{~S}$ & 100 & 7 & 233 & 15 & 28 & 28 & 1 \\
\hline & 2 & 2 & $2 S$ & 70 & 10.7 & 356 & 15 & 43 & 36 & 3 \\
\hline & & 3 & $1 \mathrm{~L}$ & 60 & 12.8 & 421 & 12 & 64 & 58 & 17 \\
\hline & & 1 & $1 \mathrm{~S}$ & 100 & 8.4 & 272 & 15 & 34 & 28 & 1.8 \\
\hline \multirow[t]{3}{*}{ Treatment D } & 1 & 2 & $2 S$ & 70 & 15.3 & 514 & 15 & 61 & 36 & 15 \\
\hline & & 3 & $1 \mathrm{~L}$ & 60 & 18.4 & 577 & 15 & 74 & 58 & 40 \\
\hline & & 1 & $1 \mathrm{~S}$ & 100 & 6.1 & 195 & 13 & 28 & 28 & 1 \\
\hline \multirow[t]{5}{*}{ Treatment E } & 1 & 2 & $2 S$ & 70 & 13.3 & 418 & 15 & 53 & 36 & 10 \\
\hline & & 3 & $1 \mathrm{~L}$ & 60 & 17.1 & 546 & 15 & 68 & 58 & 20 \\
\hline & & 1 & $1 \mathrm{~S}$ & 100 & 5.9 & 178 & 13 & 27 & 28 & 1 \\
\hline & 1 & 2 & $2 S$ & 70 & 13.7 & 397 & 15 & 55 & 36 & 5 \\
\hline & & 3 & $1 \mathrm{~L}$ & 60 & 18.1 & 549 & 15 & 72 & 58 & 30 \\
\hline \multirow[t]{3}{*}{ Treatment $\mathrm{K}$} & & 1 & $1 \mathrm{~S}$ & 100 & 5 & 146 & 13 & 23 & 28 & 0.8 \\
\hline & 2 & 2 & $2 S$ & 70 & 10.4 & 307 & 15 & 42 & 36 & 3 \\
\hline & & 3 & $1 \mathrm{~L}$ & 60 & 22.4 & 659 & 15 & 90 & 58 & 90 \\
\hline
\end{tabular}

L - large nozzle; $\mathrm{S}$ - small nozzle

The 1 year ARI was achieved in most simulation runs that targeted that particular ARI intensity. The 5 year ARI was not always achieved, but the majority are within the range 3 to 5 years ARI. Much less success was obtained in achieving the $10 \mathrm{yr}$ ARI rainfall intensity, and some of the simulations are in excess of 20 yrs ARI. There is no apparent reason for this variation in the 20 year target rainfall intensity. The variation among rain gauges for each simulation at each plot is acceptable, although highly variable gauges have been removed.

\section{Discussion}

From the rainfall and runoff data a number of relationships were developed for rainfall and runoff, time of concentration, and hydraulics of the flow. Some are shown in Figure 4.

The sediment data collected during the experiments, and not the subject of this paper, provided information on the behaviour of the different road surfaces. All of the data provided the basis for the design guidelines that were subsequently published [17]. 


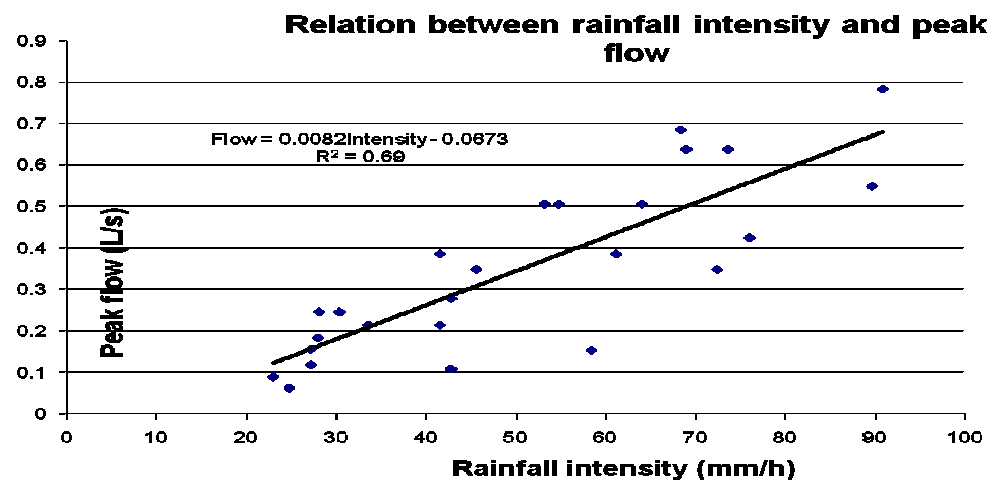

Rainfall volume versus runoff and loss volume

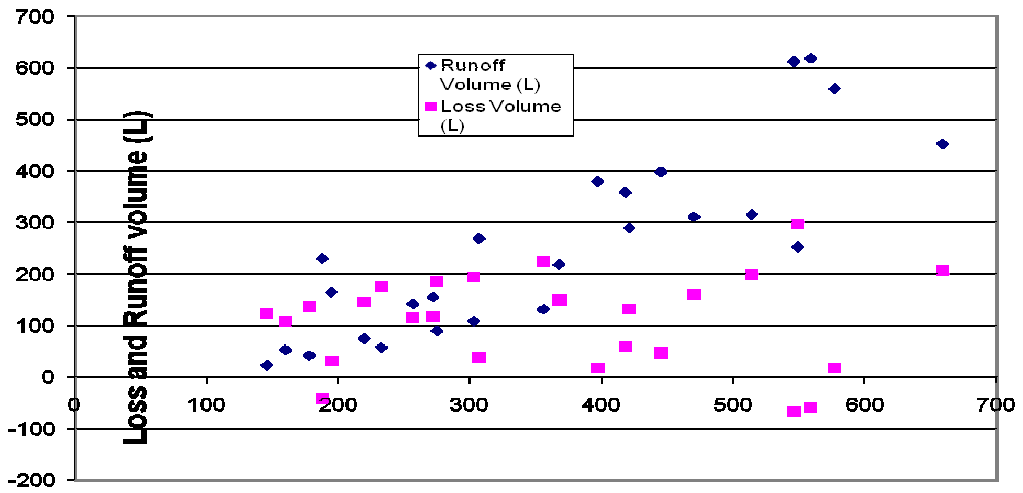

Rainfall volume (L)

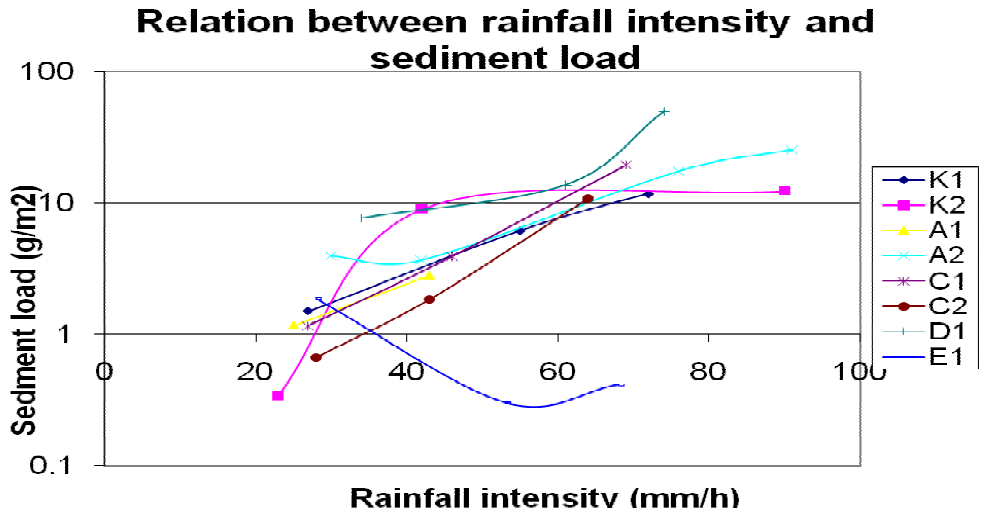

Figure 4: Relationships between rainfall intensity and volume and runoff and sediment loss. 


\section{Conclusion}

The short period of time available for the simulation experiments did not allow collection of all the data originally intended. Nevertheless, there is sufficient hydrologic data to interpret sediment load information and compare plots on the basis of ARI and runoff.

The data suggest that there are no significant beneficial impacts of the treatments on sediment loss from the roads except for the bitumen emulsion surfacing. All the experiments were conducted after a period during which normal traffic used the road. Hence, the road surface was subject to loading and wear. Whether the bitumen surfacing would maintain its integrity in the longterm is another issue.

The last 5 minutes of runoff and sediment discharge were examined for each of the simulation run. There were no discernable relations between runoff and sediment loss in the last five minutes and the different treatments.

The results of this experiment suggest that concentrating on the roadside collection and filtering systems may better achieve reductions in the off-site impacts of road runoff. The different road stabilisation methods did not appear to significantly reduce the loss of sediment from the roads, other than when the surface was treated with a bitumen emulsion.

\section{Acknowledgements}

We thank Alison Kemp for involving us in the project, the several volunteers and colleagues from other universities and local government who comprised the project team.

\section{References}

[1] Harr, R.D. and R.A. Nichols. Stabilizing Forest Roads to Help Restore Fish Habitats: A Northwest Washington Example. Fisheries 18(4): 18-22. 1993

[2] Ziegler, A.D., Sutherland, R.A. and Giambelluca, T.W. Partitioning total erosion on unpaved roads into splash and hydraulic components: the roles of interstorm surface preparation and dynamic erodibility. Water Resources Research, 36(9), 2787-2791. 2000

[3] Croke, J. and Mockler, S. Gully initiation and road-to-stream linkage in a forested catchment, southeastern Australia. Earth Surface Process and Landforms, 26,205-217. 2001.

[4] Luce, C.H. and Wemple, B.C. Introduction to special issue on hydrologic and geomorphic effects of forest roads. Earth Surface Processes and Landforms, 26(2), 111-113. 2001

[5] Cerda, A. Soil water erosion on road embankments in Eastern Spain. Science of the Total Environment, 378,151-155. 2007

[6] Sheridan, G. and Noskie, P. A quantitative study of sediment delivery and stream pollution from different forest road types. Hydrological Processes, 21, 387-398. 2007 
[7] Grace, McFero, J. III; Elliot, W.J. Determining soil erosion from roads in coastal plain of Alabama In Proc.; Environmental Connection 08, Proceedings of Conference 39, Orlando, FL, International Erosion Control Association, Steamboat Springs, CO. 2008

[8] Australian Government. Department of Infrastructure (2007). Transport, Regional Development and Local Government, Bureau of Infrastructure, Transport and Regional Economics, Australian Transport Statistics. Canberra. 174pp. 2007

[9] Riley, S.J. and Hancock, F. A rainfall simulator for hydrologic and erosion experiments on mines, with an example of its applications at Ranger Uranium Mine, Northern Territory, Australia. The Australasian Institute of Mining and Metallurgy Proceedings. 1: 3-8. 1997

[10] Lascelles, B., Favis-Mortlock, D.T., Parsons, A.J. and Guerra, A.J.T. Spatial and temporal variations in two rainfall simulators: implications for spatially explicit rainfall simulation experiments. Earth Surface Processes and Landforms, 25,709-721. 2000

[11] Parsons, A.J. and Lascelle, B. Rainfall simulation in geomorphology. Earth Surface Processes and Landforms, 25, 679. 2000

[12] Herngren, L., Goonetilleke, A., Ayoko, G.A. Investigation of urban water quality using artificial rainfall. Proc International Conference: Watershed 2004. Dearborn, Michigan 16pp. 2004

[13] Herngren, L., Goonetilleke, A., Ayoko, G.A. Understanding heavy metal and suspended solids relationships in urban stormwater using simulated rainfall. J Environmental Management, 78(2),149-158. 2005

[14] Adams, R and Elliot, S. Physically based modelling of sediment generation and transport under a large rainfall simulator. Hydrological Processes, 20,2253-2270. 2006

[15] Dunkerley, D. Rain event properties in nature and in rainfall simulation experiments: a comparative review with recommendations for increasingly systematic study and reporting. Hydrological Processes. 2008.

[16] Riley, S.J. and Shrestha, S.. Rainfall simulation experiments on roads. In Panigrahi, B.K., Babel, M.S., Parkpian, P., Webb, J.W., Koottatep, T., Dacera, Do (eds). Proceedings An International Perspective on Environmental and Water Resources. Bangkok, Thailand 5-7 Jan 2009. American Soc Civil Engineers, Environmental and Water Resources Institute Abstract page 60. CD pages 1-10. 2009

[17] Kemp, A. Sediment control on unsealed roads: a handbook of practical guidelines for improving stormwater quality. EPA Victoria and Cardinia Shire Council. 42pp 2004 